\title{
Penerapan Self Help Menggunakan Ayat-ayat al-Qur'an (Studi Naratif Menghadapi Jatuh Cinta dan Patah Hati)
}

\author{
Putri Laras Trisnawati \\ Universitas Negeri Malang \\ putri.laras.1901117@students.um.ac.id \\ Maya Tsuroya Alfadla \\ Universitas Negeri Malang \\ mayatsuroya@gmail.com
}

\begin{abstract}
Mental health is currently a growing issue in Indonesia. Mental health is a balanced state and the achievement of individual development tasks. Individuals who are facing poor mental health will develop self-narratives that tend to be destructive. Self-narrative is an individual's life story consisting of values, experiences and identities that are internalized into a belief and personality. Selfdestructive narratives affect individual development. Problems that are closely related to depression experienced by individuals are falling in love and heartbreak. These problems provide stress effects to depression to individuals. Depression contributes the greatest value to suicide rates. The method used is qualitative research with narrative approach. The subject strengthens his inner values through the study of the verses of the Qur'an and self-evaluation in a series of self-help processes. Self help consists of the process of understanding the values of life in the verses of the Qur'an, evaluating relationships with the Almighty and preparing for the worst. The subject has a perspective and meaning related to falling in love and broken heart experienced and internalized into selfnarration. Self-narration is developed based on the results of selfhelp that is done so that it can bring up new meanings in life.
\end{abstract}

Keywords: Self Help; Self-Narration; Falling in Love; Broken Hearts; al-Qur'an Verses 


\begin{abstract}
Abstrak
Kesehatan mental saat ini menjadi isu yang berkembang di Indonesia. Kesehatan mental merupakan keadan seimbang dan tercapainnya tugas perkembangan individu. Individu yang sedang menghadapi kesehatan mental yang buruk akan mengembangkan narasi diri yang cenderung destruktif. Narasi diri merupakan kisah hidup individu yang terdiri dari nilai, pengalaman dan identitas yang diinternalisasi menjadi sebuah kepercayaan dan kepribadian. Narasi diri yang bersifat destruktif mempengaruhi perkembangan individu. Permasalahan yang erat kaitannya dengan depresi yang dialami oleh individu adalah jatuh cinta dan patah hati. Permasalahan tersebut memberikan efek stress hingga depresi kepada individu. Depresi menyumbang nilai terbesar pada angka bunuh diri. Metode yang digunakan adalah penelitian kualitatif dengan pendekatan naratif. Subyek menguatkan nilai-nilai dalam dirinya melalui pengkajian ayatayat al-Qur'an dan evaluasi diri dalam rangkaian proses self help. Self help terdiri dari proses memahami nilai-nilai kehidupan dalam ayat-ayat al-Qur'an, evaluasi hubungan dengan yang Maha Kuasa dan mempersiapkan diri untuk kemungkinan terburuk. Subyek memiliki cara pandang dan pemaknaan terkait dengan jatuh cinta dan patah hati yang dialami dan diinternalisasi menjadi narasi diri. Narasi diri dikembangkan berdasarkan hasil self help yang dilakukan sehingga dapat memunculkan pemaknaan baru dalam kehidupan.
\end{abstract}

Kata Kunci: Self Help; Narasi diri; Jatuh Cinta; Patah Hati; Ayat-ayat al-Qur'an

\title{
Pendahuluan
}

Individu semasa hidup mengembangkan konstruk diri terhadap pengalaman dan nilai yang terus berkembang. Proses tersebut dipengaruhi oleh beragam kejadian yang dimaknai dan dikembangkan serta diinternalisasi. Proses internalisasi tersebut membentuk sebuah narasi diri yang menceritakan tentang keadaan diri. Narasi diri merupakan kisah tentang diri yang terdiri dari beragam pengalaman, nilai dan identitas. Remaja merupakan masa pembentukan identitas. Tahap perkembangan tersebut merupakan fase pembentukan identitas versus kebingungan identitas. Individu berusaha mencari jadi diri untuk membentuk identitas. Pada fase ini rentan untuk individu mencoba peran dan tugas yang menyimpang sebagai bentuk percobaan dalam menemukan identitas. Identitas yang dibentuk akan dikembangkan dalam komponen narasi diri setiap individu. 
Proses pembentukan identitas moralitas dijelaskan dalam tahap perkembangan yaitu identitas versus kebingungan identitas ${ }^{1}$. Remaja pada tahap ini dihadapkan pada pertanyaan siapa dirinya, tujuan hidup dan kemana arah kehidupannya. Remaja memiliki kecenderungan mencari identitas budaya dan bereksperimen dengan berbagai peran dan kepribadian. Remaja yang berhasil membentuk identitas akan muncul perasaan diri baru dan yang mengalami kegagalan pembentukan identitas akan mengalami kebingungan identitas. Identitas merupakan dimensi sosial dari pribadi yang melibatkan pengakuan oleh diri dan announcements dan penempatan oleh orang lain sebagai penentu identitas. ${ }^{2}$ Jenis identitas yang dikembangkan dalam proses kehidupan menurut model konseling intensif progresif adaptif terhadap struktur (KIPAS) terdiri dari jenis kelamin dan gender, etnisitas, sistem nilai/religi, strata sosial atau kelas sosial ekonomi dan jalur pendidikan atau pekerjaan diakronimkan menjadi JENiS-PK. ${ }^{3}$

Identitas dikembangkan dalam narasi diri yang diinternalisasi dan mempengaruhi perilaku individu. Narasi diri berkembang berdasarkan dengan nilai yang dianut setiap individu. Narasi yang diinternalisasi dalam diri akan membentu kepribadian individu. Salah satu faktor pembentuk kepribadian berfokus pada narasi hidup. ${ }^{4}$ Narasi dalam diri memiliki nilai keyakinan yang tinggi setelah mengalami proses internalisasi. ${ }^{5}$ Narasi diri membentuk kepribadian berdasarkan cerita seseorang untuk menjelaskan kehidupan mereka. ${ }^{6}$ Narasi yang dibuat mencerminkan kebutuhan dan menjustifikasi tindakan yang dilakukan oleh individu. Cerita-cerita yang diceritakan tentang diri sendiri memberikan peran penting dalam membentuk kepribadian seseorang. Narasi dalam kehidupan individu tidak terlepas dari nilai diri atau personal value yang berkembang selama kehidupan.

${ }^{1}$ Santrock, John. Life-Span Development: Seventeenth Edition. New York: McGraw Hill Education, 2019.

${ }^{2}$ Mappiare, Andi. "Meramu Model Konseling Berbasis Budaya Nusantara: KIPAS (Konseling Intensif Progresif Adaptif Struktur)." Pidato Pengukujan Jabatan Guru Besar dalam

Bidang Ilmu Bimbingan dan Konseling. Malang: Universitas Negeri Malang, 2017.

3 Mappiare, Andi. "Meramu Model Konseling Berbasis Budaya Nusantara: KIPAS (Konseling Intensif Progresif Adaptif Struktur)." Pidato Pengukujan Jabatan Guru Besar dalam Bidang Ilmu Bimbingan dan Konseling. Malang: Universitas Negeri Malang, 2017.

${ }^{4}$ Carole Wade, Carol Tavris, Maryanne Garry. Psychology, Eleventh Edition. Canada: Pearson Education, Inc., 2014.

5Abels, Sonia. Understanding Narrative Therapy : A Guidebook For The Social Worker. New York: Springer Publishing Company Inc., 2001.

6 Abels, Sonia. Understanding Narrative Therapy : A Guidebook For The Social Worker. New York: Springer Publishing Company Inc., 2001. 
Personal values adalah kepercayaan dan filosofi yang diyakini tentang kehudupan, tujuan dan peraturan untuk bersikap dan bertindak. ${ }^{7}$ Personal values terkait dengan pilihan yang mengarahkan keputusan yang dibuat oleh individu. Proses perkembangan pada masa awal kehidupan kita menerima nilai-nilai pribadi orang lain disekitar kita dan terus berkembang hingga menetapkan pilihan untuk menerima atau menolak nilai untuk diiternalisasikan. Nilai dapat berasal dari sistem masyarakat, budaya, dan agama. Personal values dipengaruhi oleh keluarga, pengalaman, komunitas, bangsa, budaya dan lingkungan historis individu. Personal value berkembang seiring interaksi dengan dunia luar dan dapat berubah sepanjang proses kehidupan. Integritas dalam penerapan nilai mengacu pada konsistensi individu dalam menerapkan nilai dengan tepat terlepas dari penguatan negatif dari orang lain.

Personal value merupakan hal yang dianggap penting oleh setiap diri individu. Individu yang merasa tidak puas dengan kehidupan, pekerjaan atau suatu pencapaiannya dapat dikarenakan oleh perbedaan dengan personal values individu. ${ }^{8}$ Mengidentifikasi nilai memudahkan untuk membuat pilihan terbaik terkait dengan pekerjaan, keuangan, pendidikan dan keseluruhan aspek kehidupan. Empat langkah untuk menganalisis personal values terdiri dari (1) memilih daftar selektif dengan mempersempit pada sepuluh pilihan utama; (2) memaknai nilai yang dipilih dan alasan mengapa nilai itu penting; (3) membuat urutan prioritas dari sepuluh pilihan nilai yang sudah dipilih; (4) beri nilai 1-10 untuk kemungkinan penerapan dalam kehidupan sehari-hari. ${ }^{9}$ Penelitian nilai oleh Milton Rokeach dalam bukunya The Nature of Human Values menyebutkan bahwa nilai adalah keyakinan abadi tentang cara berperilaku khusus dan tujuan hidup spesifik yang lebih disukai untuk diterapkan dalam diri individu maupun dalam kelompok sosial. ${ }^{10}$ Personal value merupakan nilai keyakinan yang memiliki arti bagi setiap orang sevara individu. Personal value memiliki komponen kognitif, afektif dan perilaku. Nilai merupakan sesuatu yang stabil diterapkan dan dapat diukur. Ada dua jenis nilai yang menggambarkan perilaku dan tujuan hidup. Nilai terkait dengan apa yang diinginkan merupakan nilai kognitif. Nilai afektif memiliki arti bahwa terdapat ikatan emosional terkait dengan nilai tersebut. ${ }^{11}$

${ }^{7}$ Highland Consulting Group. Leading With Impact: Your Ripple Effect. Artikel Online, www.AskRoxi.com, 2014.

${ }^{8}$ Barbara, Santa. Circle of Life. Artikel Online, http://www.circleoflife.net, 2011.

9 England, G. W. (1967). Personal value systems of American managers. Academy of Management journal, 10(1), 53-68.

${ }^{10}$ Golden, John. "Understanding Your Personal Values: A Clarification Companion Guide To The Values Arrangement List ${ }^{\mathrm{TM}}$ Assessment.” Trademark of Golden LLC, 2016.

11 Budiningsih, C. A. (2009). Mengembangkan Nilai-Nilai Afektif Dalam Pembelajaran. Yogyakarta: KTP-FIP UNY. 
Nilai-nilai manusia bersifat universal namun didefinisikan secara berbeda untuk setiap individu. Nilai merupakan bentukan dari budaya, masyarakat, lembaga, organisasi dan kepribadian setiap individu. ${ }^{12}$ Konsekuensi nilai dapat diamati dalam fenomena dan perilaku. Nilai merupakan seperangkat standart komples yang memandu atau menjalankan kehidupan dalam berbagai cara. Nilai bersifat khas yang tidak sama dengan orang lain dalam mepersepsikannya dalam kehidupan sehari-hari. Nilai merupakan penentu keinginan dalam kehidupan, cara berperilaku dan cara mendapatkan keinginan tersebut. Nilai menentukan penggunaan waktu, sumber daya dan energi dalam berperilaku. Aristoteles mengidentifikasi dua jenis nilai yaitu nilai terminal dan instrumental. Nilai terminal berarti nilai akhir kehidupan dan makna instrumental bahwa memenuhi pencapaian dari nilai terminal. ${ }^{13}$

Carl E. Pickhardt Ph.D menyebutkan bahwa patah hati paling menyakitkan adalah pada usia remaja. Apabila dikaitkan dengan tahap perkembangan berdasarkan standart kompetensi kemandirian peserta didik (SKKPD). ${ }^{14}$ SKKPD memiliki sebelas aspek yang dikembangkan berdasarkan tahapan perkembangan siswa sekolah menengah atas dan perguruan tinggi. SKKPD terdiri dari sebelas aspek perkembangan siswa yaitu aspek landasan hidup religius, aspek kematangan intelektual, aspek kesadaran gender, aspek pengembangan pribadi, aspek hubungan dengan teman sebaya, aspek kematangan emosi, aspek perilaku etis, aspek kesadaran tanggung jawab sosial, aspek perilaku kewirausahaan, aspek wawasan dan kesiapan karir dan aspek kesiapan diri untuk menikah dan berkeluarga. ${ }^{15}$ Remaja memiliki tugas perkembangan untuk mengenal lawan jenis melalui hubungan teman sebaya dan kesiapan diri untuk menikah. Remaja mengembangkan identitasnya melalui hubungan sebaya dan membentuk rasa cinta dari hubungan tersebut.

Tugas perkembangan yang terpenuhi memberikan keseimbangan dan ketentraman batin bagi setiap individu. Keseimbangan tersebut sesuai dengan pendapat Rogers yang menyatakan bahwa kondisi kongruen ketika adanya kesesuaian antara ideal self dan real self. Ideal self merupakan diri ideal yang dikonsep kan oleh individu dan real self adalah keadan diri yang sesunguhnya. Ketidaksesuaian antara keduanya memunculkan kecemasan dalam diri individu. Tugas perkembangan dan kesimbangan real self dan ideal self merupakan salah satu penyebab terganggunya kesehatan mental individu. Kesehatan mental yang

12 Mustari, M., \& Rahman, M. T. (2011). Nilai karakter: Refleksi untuk pendidikan karakter.

13 Diana, I. N. (2012). Organizational Citizenship Behavior (OCB) dalam Islam. Jurnal Ilmu Ekonomi dan Sosial, 1(2), 141-148.

${ }^{14}$ Dhani, Arman. Mati karena Patah Hati. Berita Online, Jakarta: https://tirto.id, 2016.

15Permendikbud. "Peraturan Menteri Pendidikan Dan Kebudayaan Republik Indonesia Nomor 20 Tahun 2018 Tentang Penguatan Pendidikan Karakter Pada Satuan Pendidikan Formal." Salinan Peraturan Menteri. Jakarta, 2018. 
baik adalah kondisi batin dalam keadaan tentram dan tenang sehingga membuat diri bisa meninkmati kehidupan sehari-hari dan menghargai orang lain. ${ }^{16}$ Jenis masalah yang menggangu kesehatan mental beberapa diantaranya adalah stress, gangguan kecemasan dan depresi. Depresi menyumbang angka tertinggi pada kasus bunuh diri. Depresi merupakan kesedihan berlarut-larut yang menyebabkan masalah fisik, cara berperilaku dan cara berpikir. Pemicu depresi terdiri dari peristiwa hidup yang memunculkan stress, kehilangan orang yang dicintai, dan memiliki kepribadian yang rapuh.

Kasus bunuh diri 17 februari 2020 di flyover pasar senin menujukkan terdapat permasalahan tentang kesehatan mental. Motif bunuh diri pada kasus ini adalah persoalan cinta dikarenakan kekasih pelaku telah berkencan dengan pria lain. ${ }^{17}$ Kasus lain terjadi pada mahasiswa asal Bali yang nekat mengakhiri hidupnya diduga kuat karena putus cinta. ${ }^{18}$ Kejadian tersebut terjadi lantaran rasa cemburu kepada mantan pacar pelaku. Pengelolan emosi diri yang kurang tepat diimbangi dengan narasi diri yang bersifat destruktif memberikan pengaruh kuat terhadap resiko depresi dan bunuh diri. Kasus bunuh diri di Indonesia menurut organisasi kesehatan dunia (WHO) menyebutkan bahwa pada tahun 2016 dengan nilai 3,7 per seratus ribu orang. WHO menyatakan bahwa banyak kasus bunuh diri dan percobaan bunuh diri yang luput dari survai dikarenakan isu tabu perhadap permasalahan bunuh diri di Indonesia. ${ }^{19}$

Perasaan cinta merupakan perasaan yang muncul sesuai tahap perkembangan remaja yang terjadi pada masa pubertas. Perasaan ini berkembang melalui ketertarikan terhadap lawan jenis. Ketertarikan dikarenakan masalah hormonal ini yang perlu menjadi perhatian remaja dalam mengelolanya. Remaja berdasarkan teori identitas Erikson sedang berada pada penemuan identitas hal tersebut berlaku juga dalam hal cinta. Remaja mengembangkan sikap yang seharusnya dibentuk ketika memiliki ketertarikan dengan lawan jenis dan lingkungan memiliki peran penting terhadap pembentukan ini. Individu sesuai dengan kebutuhan Glasser memiliki kebutuhan dasar yang terdiri dari survival, love and belonging, freedom, power dan fun. Kebutuhan tersebut berhubungan dengan kebutuhan untuk mempertahankan hidup seperti makan, minum, tempat tinggal dan lain-lain. Kebutuhan lainnya yaitu kebebasan dalam artian berdiskusi, berkelompok, beragama dan lain-lain. Kebutuhan akan pengakuan dalam masyarakat dan bersenang-senang merupakan komponen dasar yag dibutuhkan

\footnotetext{
${ }^{16}$ Corey, Gerald. Theory and Practice of Counseling and Psychotherapy Tenth Edition. Boston: Cengage Learning, 2017.

${ }^{17}$ Fardiansyah, Achmad. Begini Kronologi Pria Nekat Loncat dari Flyover Senen. Berita Online, Jakarta: https://megapolitan.okezone.com, 2020.

${ }^{18}$ Amiruddin, Herman. Terbakar Api Cemburu,Mabasiswa Gantung Diri di Kamar Kost. Artikel Online, Jakarta: https://news.okezone.com, 2020.

${ }^{19}$ Damarjati. Tingkeat Bunuh Diri Indonesia Dibanding Negara-negara Lain. Berita Online, https://news.detik.com, 2019.
} 
manusia. Kebutuhan akan love and belonging berkembang selama masa kehidupan mulai dari kasih sayang dengan orang tuas, keluarga dan teman sebaya. Kebutuhan tersebut mengontrol tindakan yang dilakukan. Remaja yang memenuhi kebutuhannya akan cenderung memenuhinya tanpa mempertimbangkan nilai dan norma yang ada pada diri dan masyarakat. Remaja siap untuk jatuh cinta namun tidak siap untuk menerima penolakan dan kehilangan. Hal tersebut dengan tingginya tingkat bunuh diri di Indonesia.

Bunuh diri merupakan kejadian dengan faktor depresi sebagai penyebab tertinggi. Depresi banyak diakibatkan oleh permasalahan putus cinta atau patah hati. ${ }^{20}$ Perilaku remaja yang masih pada tahap pembentukan identitas memberikan sumbangan terhadap perilaku yang tidak sesuai dengan nilai dan norma yang berlaku. Narasi diri yang bersifat destruktif yang dibentuk dari pengalaman dan nilai yang diinternalisasi akan ikut mempengaruhi proses pembentukan kepribadian individu. Individu melakukan banyak hal dalam menghadapi rasa cinta dan sakit hati. Cara tersebut unik dan bermakna dalam proses kehidupan individu. Proses self help merupakan proses untuk menolong diri dalam proses pemaknaan dan pembentukan narasi diri oleh konseling. Proses self help memberikan kontribusi dalam pembentukan narasi diri yang produktif untuk menjaga kesehatan mental individu. Pengalaman menghadapi jatuh cinta dan kehilangan akan dibahas menggunakan penelitian kualitatif pendelatan naratif untuk mengelola kisah kronologis secara mendalam dalam melakukan self help menggunakan bacaan al-Qur'an.

Masalah penelitian yang diidentifikasi berdasarkan kisah yang diceritakan mengambil sudut pandang narasi diri self help menggunakan al-Qur'an dalam masalah cinta dan kehilangan. Masalah tersebut dianalisis berdasarkan kisah dominan subyek penelitian yang mampu dilewati menggunakan self belp menggunakan al-Qur'an. Fokus pengalaman yang dikembangkan adalah narasi diri berkaitan dengan self help menggunakan al-Qur'an dalam mengatasi permasalahan jatuh cinta dan kehilangan. Subyek memiliki narasi dominan terkait permasalahan penyembuhan mentalnya setelah mengalami patah hati dalam usaha rencana pernikahan. Cerita-cerita yang diceritakan tentang diri sendiri memainkan peran penting dalam membentuk kepribadian unik seseorang. ${ }^{21}$ Berdasarkan beberapa pendapat diatas pendekatan naratif akan memberikan pemaknaan cerita hidup positif sebagai pembelajaran dan penguatan identitas diri melalui bacaan al-Qur'an. Michael White dan David Epston menyebutkan bahwa individu membangun makna hidup melalui cerita

\footnotetext{
${ }^{20}$ Dhani, Arman. Mati karena Patah Hati. Berita Online, Jakarta: https://tirto.id, 2016.

${ }^{21}$ Carole Wade, Carol Tavris, Maryanne Garry. Psychology, Eleventh Edition. Canada: Pearson Education, Inc., 2014.
} 
interpretatif yang diinternalisasi sebagai kebenaran. Narasi tersebut yang akan dieksplorasi sebagai pemaknaan dari kisah jatuh cinta dan patah hati ${ }^{22}$.

Tujuan penelitian ini adalah untuk mengetahui proses pengalaman menghadapi jatuh cinta dan patah hati. Subyek menggunakan pendekatan self help menggunakan bacaan al-Qur'an dalam membantu dirinya menemukan pemaknaan atas pengalaman yang dihadapi. Tujuan difokuskan kepada proses bangkit setelah menghadapi kejadian yang menggangu mental. Pemfokusan pada narasi diri setelah melakukan self help menggunakan bacaan al-Qur'an memberikan gambaran membantu diri menjaga kesehatan mental dalam menghadapi jatuh cinta dan patah hati.

Metode penelitian yang digunakan adalah penelitian kualitatif dengan pendekakatan naratif. Penelitian naratif digunakan ketika subyek mampu menceritakan kisahnya melalui sudut pandang praktis dan spesifik. ${ }^{23}$ Penelitian naratif digunakan berdasarkan urutan peristiwa kronologis. Penelitian ini lebih luas membahasa tentang norma dan nilai budaya seperti etnografi atau teori abstrak $^{14}$. Subyek penelitian ditentukan menggunakan teknik purposive sampling. Purposive sampling adalah pemilihan sampel disesuaikan dengan tujuan utama penelitian. ${ }^{24}$ Teknik sampling ini dilakukan dengan memilih subyek yang mampu menarasikan dirinya melalui kisah jatuh cinta dan kehilangan. Subyek yang dipilih terdiri dari satu orang dengan kisah jatuh cinta dan kehilangan terhadap calon suami. Instrumen yang digunakan dalam penelitian ini adalah wawancara mendalam.

Tahapan penelitian naratif terdiri dari (1) identifikasi masalah penelitian; (2) tinjauan literatur; (3) mengembangkan tujuan penelitian dan pertanyaan penelitian; (4) Mengumpulkan data kualitatif; (5) analisis dan interpretasi data kualitatif; (6) menulis dan evaluasi penelitian. ${ }^{25}$ Identifikasi masalah penelitian dilakukan dengan melakukan eksplorasi pengalaman melalui kisah-kisah hidup yang diceritakan subyek penelitian. Tinjauan literatur dilakukan seminimal mungkin dan fokus kepada pengalaman individu. Tujuan penelitian dan pertanyaan penelitian disusun setelah melakukan kedua tahapan sebelumnya dengan mengeksplorasi makna pengalaman individu. Tujuan disusun secara luas dan umum dan digunakan untuk mengeksplorasi pengalaman individu.

Subyek merupakan perempuan usia 24 tahun. Subyek tinggal dalam lingkungan pondok pesantren sejak sekolah dasar. Subyek hidup jauh dengan

\footnotetext{
${ }^{22}$ Corey, Gerald. Theory and Practice of Counseling and Psychotherapy Tenth Edition. Boston: Cengage Learning, 2017.

${ }^{23}$ Creswell, John. Educational Research : Planning,Conducting and Evaluating Quantitative and Qualitative Research. Boston: TexTech International, 2012.

${ }^{24}$ Sugiyono. Metode Penelitian Bisnis. Bandung: Pusat Bahasa Depdinas, 2003.

25 Creswell, John. Educational Research : Planning, Conducting and Evaluating Quantitative and Qualitative Research. Boston: TexTech International, 2012.
} 
orang tua dan tinggal bersama kakek, nenek dan saudara lainnya dalam lingkungan pondok pesantren. Subyek sedang menempuh pendidikan magister. Subyek merasa telah memiliki kesiapan dalam menyegerakan hubungan yang halal melalui ikatan pernikahan. Ikatan pernikahan dipengaruhi oleh nilai-nilai kepercayaan agama dan tradisi setempat ${ }^{26}$. Hal tersebut mempengaruhi usia ideal pernikahan serta peran diri sebagai seorang istri dan suami atau perempuan dan laki-laki.

\section{Hasil dan Pembahasan}

Proses perkenalan dengan calon pasangannya melalui kegiatan organisasi beasiswa santri. Perkenalan mereka berfokus pada hubungan yang lebih serius yaitu pernikahan. Akhir bulan Februari 2020 pembicaraan mereka mengarah pada mahar dan percakapan persiapan khitbah/lamaran. Bulan ramadan yaitu April 2020 merupakan bulan yang dipilih subyek untuk mempertemukan keluarga kedua calon pengantin. Ayah subyek yang berada di daerah Sumatra berniat untuk pulang ke Jawa Timur yaitu tanah kelahiran beliau untuk menerima lamaran dari calon pengantin. Subyek mengatakan bahwa :

"Bulan Mei besok InsyaAllah saat Ramadhan Babe pulang ke Ponorogo untuk menemui keluarga pihaklaki-laki menyepakati hari dan memastikan lamaran. Bulan yang direncanakan semakin dekat namun tanggalnya semakin jauh, nyatanya rencana tersebut tak jadi terealisasi”

Awal bulan maret 2020 subyek menerima pesan teks melalui aplikasi whatsapp mesegger sebuah pesan yang menjelaskan sebuah kisah tentang patah hati. Calon pasangan subyek merupakan seorang santri. Calon pasangan subyek melakukan soan/kunjungan kepada kyai dan mengikuti prosedur yang disarankan salah satunya yaitu melakukan sholat istiqoroh. Hal tersebut dilakukan oleh calon pasangan subyek untuk memantabkan hati atas dua pilihan yang sama-sama baik menurutnya. Proses sholat istiqoroh yang dijalani teryata memunculkan nama lain selain subyek yang dianggap sebagai jawaban. Jawaban atas sholat istigoroh yang dilakukan harus dijalankan dan disegerakan. Hal tersebut berarti bahwa calon pasangan subyek memilih orang lain yang akan mendampingi dalam pernikahannya. Kisah patah hati ini merupakan kisah keempat yang dialami oleh subyek. Subyek sebelumnya telah mengalami tiga rencana pernikahan yang tidak sempat berlanjut pada tahap khitbah. Rasa terpukul akan kegagalan yang dihadapi untuk keempat kalinya membuat subyek memberikan respon senyuman pada saat membaca pesan yang diberikan. Pesan yang mengobrak-abrik hatinya hanya disampaikan melalui pesan teks yang membuat subyek merasa tidak dihargai. Subyek mengatakan

${ }^{26}$ Santrock, John. Life-Span Development: Seventeenth Edition. New York: McGraw-Hill Education, 2019. 


\begin{abstract}
"Sebenarnya saya merasa kurang dihargai dengan keputusan yang disampaikan melalui pesan teks, namun dawub kyai untuk segera menyelesaikan urusan dengan calon yang namanya tidak muncul dalam jawaban istiqoroh dan tidak boleh menunda lagi untuk segera meminang nama yang telah muncul sebagai petunjuk. Setelah itu saya seharian di kampus menyelesaikan kewajiban dan merenung lama saat sholat ashar disana saya baca lagi terus berulang-ulang surat yang relate dengan masalah saya"
\end{abstract}

1. Analisis masalah

Narasi diri yang berkembang pertama kali setelah menerima kabar tersebut adalah kenapa harus saya lagi Ya Allah? Apakah tiga kali kejadian yang sama belum cukup?. Harapan yang disematkan pada sang calon pasangan membuat subyek merasakan kekecewaan. Subyek menyebutkan berbagai kemungkinan yang menjadi penyebab kegagalannya lagi pada proses menemukan jodoh. Subyek mempertanyakan apakah terlalu banyak dosa yang saya lakukan? Apa hal yang kurang lagi untuk menemukan jodoh?. Subyek mencoba untuk berfikir jernih atas permasalahan yang dihadapi.Subyek mematikan handphonenya sebagai langkah pertama yang dilakukan. Subyek mengambil air wudhu dan melaksanakan sholat sunnah dan bercerita kepada Sang Khalik. Subyek melakukan dialog dengan Sang Maha Kuasa dalam sholat dan berkeluh kesah serta menumpahkan segala beban. Pengkomunikasian emosi dipengaruhi oleh aturan budaya yang mengatur aturan tampilan (display rules). Budaya tertentu mengisaratkan tangisan sebagai ungkapan kesedihan, senyuman sebagai ungkapan kesedihan namun ada budaya lain menggunakan tarian dan lagu sebagai ekspresi kesediahan. ${ }^{27}$

\title{
2. Pengentasan masalah
}

Hal selanjutnya yang dilakukan oleh subyek adalah membaca Al-Qur'an dan meniatkan untuk mendekatkan diri pada Sang Pencipta. Al-Qur'an yang dibacanya menujukkan dua ayat utama yang dirasa sesuai dengan keadaan diri saat itu. Surat Az-Dzariyat ayat 49-51 memiliki arti "Dan segala sesuatu Kami ciptakan berpasang-pasangan agar kamu mengingat (kebesaran Allah)". Surat kedua yaitu Surat ke 53 yaitu An-Najm ayat 60-62 yang memiliki arti "dan kamu tertawakan dan tidak menangis, sedang kamu lengah, maka bersujudlah kepada Allah dan sembahlah Dia". Hal tersebut sesuai dengan penelitian yang pernah dilakukan sebelumnya dengan menghubungkan koping stress karna kehilanggan menggunakan spriritualitas. Koping tersebut dilakukan dengan pembuatan makna yang melibatkan konstruk kepercayaan, nilai-nilai dan tujuan untuk

\footnotetext{
${ }^{27}$ Carole Wade, Carol Tavris, Maryanne Garry. Psychology, Eleventh Edition. Canada: Pearson Education, Inc., 2014.
} 
mengubah makna terhadap situasi kehilangan ${ }^{28}$. Koping menggunakan gama berguna untuk tingkat stress yang tinggi ${ }^{20}$. Subyek mengatakan bahwa

"Saya malamnya ngechat Babe minta waktunya, saya mau telfon,saya telfon menceritakan semuanya kepada Babe, dan beliau hanya tertawa kecil mendengarkan anak gadisnya bercerita, beliau tidak menyalahkan siapapun dalam hal ini, beliau adalah sebaik-baiknya tempat bercerita setelah kepada Allah SWT. Saya beruntung memiliki Babe yang siap mendengarkan dan bijaksana dalam menyikapi segala sesuatu serta saya memiliki teman-teman yang memberikan support dan tanggapan positif terhadap situasi ini”"

Kebimbangan dan ketidakpastian seakan menjadi jelas sehingga harapan yang tidak sesuai dengan kenyataan harus diikhlaskan. Doa merupakan cara romantis yang dilakukan setiap hamba kepada Sang Maha Pembolak Balikkan Hati. Doa yang disampaikan begitu kuat sehingga memberikan petunjuk kepada hamba yang memohon. Proses mengikhlaskan bukan merupakan perkara yang mudah. Merelakan harapan dalam sebuah petunjuk yang tidak sesuai dengan rencana. Subyek menuliskan dalam puisi "Dia Sang Pencemburu" Dia Pencemburu, Dia Pemerhati Tapi Dia Maha Kasih, Menerimaku meski telah pergi, Mendekapku meski telah dikhianati, Menyayangiku meski diingkari Kemudian Dia katakan lagi, Bergembirlah dan jangan menangis, kamu hanya sedang lengah, bersujudlah pada-Ku. Potongan ayat yang dibaca oleh subyek memberikan titik terang. Subyek menjelaskan bahwa

"Saya membaca ayat tersebut berulang-ulang, saya yakin tidak ada kata terlambat untuk kembali, kesalahan saya kemarin terlalu banyak porsi yang dihabiskan untuk mencintai hambaNya, namun tidak cukup porsi untuk mencintai Sang Pencipta. Ayat tersebut memberikan saya dekapan dalam artian saya ditegur namun tidak ditinggalkan. Allah masih bersama saya dan ingin menujukkan kebesaranNya"

Jatuh cinta dan patah hati merupakan sepaket resiko dan tanggung jawab yang harus dirasa bagi pemiliknya. Subyek merasa yakin kepada sang calon dikarenakan niat baik untuk mengenalkannya pada orang tua masing-masing hingga berujung pada rencana pertemuan kedua keluarga. Subyek merasa memiliki visi dan misi yang sama dalam kehidupan untuk mengabdi pada pendidikan dan agama. Kesamaan yang disusun bersama merupakan modal awal untuk meyakinkan diri bahwa dia adalah orang yang tepat. Jatuh cinta sesederhana keyakinan diri subyek bahwa calon pasangan dapat berjuang impian yang sama dan serius menuju jenjang pernikahan. Sesederhana patah hati, subyek menuliskan dalam puisi "Dia Sang Pencemburu" bahwa doanya sangat kuat yang samar jadi terang, yang ragu jadi gamblang, yang banyak berharap harus lapang, bukankah semua buatan?. Subyek yakin bahwa semua hal yang

${ }^{28}$ Santrock, John. Life-Span Development: Seventeenth Edition. New York: McGraw Hill Education, 2019. 
telah diskenariokan oleh Sang Maha Kuasa merupakan petunjuk yang terbaik untuk setiap hamba-Nya.

Tuhan maha romantis memberikan ketenangan hati saat narasi diri mulai menyalahkan keadaan. Subyek merasa disayangi, diterima dan tidak ada kata terlambat untuk kembali. Subyek menyadari telah kehilangan banyak waktu untuk berdialog kepada Sang Pencipta melalui doa. Ayat 60-62 dalam surat Najm dan surat Az-Dzariyat ayat 49-51. Ayat tersebut menjukkan betapa besar Kuasa-Nya tentang segala sesuatu dimuka bumi ini. Ayat tersebut telah menujukkan cinta yang sesunggunya merupakan sesuatu yang suci. Jatuh cinta yang sesungguhnya adalah setelah kata "sah" terucap dari para saksi. Cinta hamba yang seharusnya ditujukan kepada Sang Pemilik Hati harus terkecoh dengan nafsu untuk memiliki hamba-Nya dan lupa sesungguhnya Allah Maha Membolak-balikkan Hati Manusia. Cinta Allah kepada mahluk melalui ayat-ayat yang diturunkan sebagai pedoman dalam Al-Qur'an memberikan petunjuk bagi setiap hamba. Subyek menuliskan "Engkau membukakan pintu lebar setelah aku keluyuran mencari kebebasan, Engkau memberikan suntikan bahagia meski kerap kali aku durhaka, Engkau memberi peringatan tapi tidak meninggalka". Ayat yang subyek baca membuka pemahaman bahwa Allah SWT dekat dan pertolongan-Nya dekat. Sang Maha Pengampun memberikan petunjuk, memberikan kebahagiaan dan memberikan kesempatan untuk kembali setelah kesalahan yang dirasakan subyek. Pada tahap ini subyek merasa sangat bersykur bahwa hatinya masih diberi keimanan sehingga tak ada kata putus atas atas kegagalan dalam kisah cinta yang dihadapi. Subyek yakin tidak ada kata terlambat untuk mencari dan kembali pada Sang Pencipta, selalu ada jalan karena hati milik Sang Kuasa. Kata tersebut dikembangkan menjadi narasi diri yang diinternaliasasikan subyek.

Pengelolan emosi negatif yang dikendalaikan melalui proses self help merupakan usaha diri untuk menjaga kesehatan mental yang baik. Kesdihan yang dibarkan berlarut-larut akan menimpulkan efek stres pada tubuh hingga depresi. Pengelolaan stress dalam pikiran dapat dilakukan dengan rasa optimisme yang dibangun dalam diri. Penelitian mengenai optimisme memberikan efek yang baik pada kesehatan dan kesejahteraan batin ${ }^{29}$. Optimisme perlu didukung oleh kesadaran dan kontrol. Kesadaran dalam mengelola perasaan dan kontrol diri terhadap situasi memberikan dukungan yang baik untuk perasaan kesedihan dan stressor yang dihadapi. Pengelolaan emosi juga dapat ditinjau dari sudut pandang spiritualitas. Penelitian menyebutkan bahwa individu dalam mengeksplorasi makna dalam kehidupan dipengaruhi oleh peran penting ${ }^{30}$. Penelitian lain menujukkan bahwa individu

\footnotetext{
${ }^{29}$ Carole Wade, Carol Tavris, Maryanne Garry. Psychology, Eleventh Edition. Canada: Pearson Education, Inc., 2014.

${ }^{30}$ Santrock, John. Life-Span Development: Seventeenth Edition. New York: McGraw-Hill Education, 2019.
} 
yang telah menemukan makna dalam kehidupannya lebih sehat, bahagia dan terhindar dari stress dari pada individu yang belum menemukan makna dalam kehidupannya ${ }^{31}$. Proses self help membantu individu untuk bangkit dari kesedihan akan kehilangan dan mengembangkan makna baru yang lebih produktif untuk kehidupan.

Proses self help yang dilakukannya merupakan tahapan dengan memahami makna dari bacaan Al-Qur'an yang dirasa sesuai dengan keadaanya pada saat itu. Pemaknaan tersebut kemudian diikuti oleh intropeksi diri dengan melihat hubungannya dengan Sang Maha Kuasa. Pemahaman makna yang dilakukan subyek memberikan ketenangan hati bahwa dia tidak sendiri ada Allah SW'T yang selalu memberikan pertolongan dan harapan baru. Pemahaman ini dikembangkan menjadi narasi diri baru oleh subyek. Narasi diri tersebut adalah "Saya merupakan hamba Allah yang banyak kesalahan namun pertolongan-Nya sungguh nyata, saya telah diberikan petunjuk dan diterima untuk mendekatkan diri lagi, kembali menata hubungan pada Allah SWT karna Dia yang menguasai hati memberikan keimanan dan Dia juga yang menentukan bahwa setiap manusia ditakdirkan untuk saling berpasang pasangan, Allah akan memberikan jalan apabila saya kembali dan memohon ampun kepada-Nya”. Narasi tersebut telah menguatkan hati subyek bahwa tidak ada yang perlu dicemaskan jatuh cinta dan patah hati merupakan rangkaian dinamika kehidupan dengan cara yang tepat.

Subyek melakukan recall ingatan yang pernah dia susun saat pertama kali berharap. Proses ini memberikan sumbangan pada proses self help yang dilakukan oleh subyek. Setiap hal dalam kehidupan dapat diusahakan semaksimal mungkin diimbangi dengan do'a kepada Allah SWT. Hasil akhir adalah milik Allah sebagai penentu setiap kejadian. Subyek telah membiasakan diri untuk memikirkan kemungkinan terburuk dalam setiap hal yang dilakukan. Hubungan yang dibangun oleh subyek berorientasi pada jenjang serius yaitu pernikahan namun subyek telah memberikan gambaran terburuk terkait karakter diri yang akan menjadi rutinitas saat setelah pernikahan dan kemungkinan terburuk saat rencana pernikahan tersebut tidak terealisasi sesuai rencana. Perencanaan kemungkinan terburuk ini memberikan gambaran bahwa manusia tidak memiliki kuasa apapun yang menentukan hasil. Perencanaan ini merupakan proses untuk menganalisis kemungkinan yang terjadi dan memperisapkan dengan baik.

Proses merencanakan kemungkinan terburuk berbeda konsep dengan keputusasaan. Perencaan merupakan proses berserah diri kepada Allah atas segala kemungkinan yang terjadi. Perencaan kemungkinan terburuk mengurangi rasa kecewa yang dirasakan subyek. Subyek percaya bahwa setiap hal memiliki dua kemungkinan besar yaitu sesuai rencana kita dan sesuai dengan rencana-

${ }^{31}$ Santrock, John. Life-Span Development: Seventeenth Edition. New York: McGraw-Hill Education, 2019. 
Nya. Kedua rencana tersebut terkadang sejalan namun juga terkadang berlawanan arah. Subyek mengelola perasaan untuk mengikblaskan yang bukan jodohnya melalui proses berpasrah rencana-Nya. Jatuh cinta dengan kemungkinan untuk menyempurnakan cinta melalui ikatan pernikahan dan kemungkinan patah hati. Petunjuk yang diberikan Allah sangat jelas melalui jawaban atas sholat istiqoroh yang dikhususkan untuk memilih antara dua pilihan yang sama-sama baik dan sholehah. Jawaban tersebut harus segera mendapatkan tindak lanjut dengan meminang yang telah dijodohkan dan menyelesaikan urusan dengan pilihan yang tidak menjadi jodohnya. Kedua kemungkinan tersebut merupakan petunjuk Sang Maha Esa menujukkan Kuasa-Nya dalam menciptakan setiap mahluk berpasang-pasangan.

Cara pengelolaan diri sebagaimana dikemukakan di atas sesuai dengan pendapat Carole Wade (dalam Handaru) dengan memikirkan kembali permasalahan yang dihadapi melalui tiga cara. Cara pertama yaitu menilai atau meninjau kembali situasi, hal tersebut dilakukan dengan melihat permasalahan yang dihadapi melalui sudut pandang yang berbeda. Proses tersebut dinamakan dengan reappraisal atau meninjau kembali. Proses meninjau kembali dapat mengibah amarah menjadi simpati, kekhawatiran menjadi menjadi tekad, dan kegagalan menjadi sebuah peluang. Cara kedua yaitu belajar dari pengalaman. Pengalamaan dapat dikonstruk melalui makna-makna spesifik yang akan digunakan sebagai acuan untuk memprediksi kemungkinan yang terjadi di masa yang akan datang. Cara ketiga yaitu membuat perbandingan sosial. ${ }^{32}$ Perbandingan sosial dapat dilakukan dengan membandingkan diri lalu dilanjutkan dengan mensyukuri keadaaan. Perbandingan menguntungkan apabila menyediakan informasi tentang cara mengatasi masalah, mengendalikan emosi saat terjadi masalah dan memperbaiki situasi yang stress. Cara perbandingan ini juga bisa didapatkan melalui pembelajaran pemaknaan narasi diri dari orang lain untuk permasalahan percintaan. Pemaknaan tersebut disampaikan dalam artikel ini berupa cara pengelolaan emosi, cara menolong diri dan cara merefleksi diri.

Ikatan yang dibangun untuk mengekspresikan cinta telah ditunjunjukkan dengan jelas yaitu melalui pernikahan. Dia Pencemburu akan memberikan teguran apabila rasa cinta dan harapan yang dibangun tidak lagi untuk-Nya. Allah Swt maha membolak balikkan hati manusia maka sebaiknya setiap hamba hanya mengharapkan Ridho-Nya. Jatuh cinta dan patah hati merupakan rasa manusiawi yang dikembangkan bahwa sejak manusia dalam kandungan. Cinta kepada orang tua, saudara, keluarga, teman, sahabat, tentangga dan lain-lain. Manusia pada dasarnya merupakan mahluk yang membutuhkan cinta dan penghargaan dalam hidupnya. Manusia melakukan berbagai cara untuk

32 Handaru, A. W., Lase, E. P. S., \& Paramita, W. (2014). Analisis perbedaan tingkat prokrastinasi ditinjau dari gender, socio-personal, locus of control, serta kecerdasan emosional: studi pada mahasiswa program studi manajemen fE UNJ. JRMSI-Jurnal Riset Manajemen Sains Indonesia, 5(2), 243-263. 
memenuhi kebutuhan tersebut namun lupa soal rasa yang menjadi resikonya yaitu patah hati. Hati apabila tidak digantungkan pada harapan yang tepat akan mudah kecewa. Patah hati terjadi ketika manusia berharap berlebih pada mahluk dan kenyataannya hal tersebut tidak sesuai dengan Takdir. Manusia belum siap dengan resiko kekecewaan ini. Hal tersebut ditunjukkan dengan banyaknya kasus depresi dan berakhir pada keputusasaan serta bunuh diri.

Faktor-faktor yang memiliki peranan penting dalam jatuh cinta dan patah hati adalah nilai-nilai dalam diri yang diinternalisasi berdasarkan pengalaman dan norma lingkungan. Jatuh cinta dan patah hati merupakan hal umum yang dialami oleh remaja sesuai dengan tugas perkembangan yaitu mempersiapkan diri untuk kehidupan berkeluarga. Jatuh cinta dan patah hati merupakan ekspresi perasaan remaja. Remaja perlu memiliki cara untuk menjaga kesehatan mentalnya menggunakan penguatan nilai-nilai spiritual. ${ }^{33}$ Nilai yang diinternalisasi mempengaruhi narasi yang dikembangkan setiap manusia sebagai salah satu pembentuk kepribadian. Proses self help melalui pemaknaan ayat alQur'an diyakini sebagai nilai yang benar dan berkembang dalam diri narasi diri. Narasi diri terdiri dari berbagai pengalaman dan nilai-nilai yang diinternalisasikan dan direapkan untuk menceritakan tentang kehidupan masing-masing individu. Proses self help dapat dilakukan oleh setiap orang dengan menganalisis nilai-nilai diri yang relevan dengan kejadian yang terjadi. Self belp selanjutnya dikembangkan menjadi narasi diri baru untuk membantu diri bangkit dari keterpurukan.

Self belp merupakan usaha mandiri yang dilakukan individu untuk menolong diri sendiri bangkit dari permasalahan. ${ }^{34}$ Subyek memiliki cara self help yang dilakukan untuk menolong dirinya ketika menghadapi permasalahan patah hati. Nilai yang diyakini melalui ayat al-Qur'an dipadukan dengan evaluasi hubungan kepada Allah SWT sebagai strategi yang digunakan untuk menengangkan diri. Penguatan nilai tersebut dapat dikembangkan untuk narasi diri yang lebih produktif pada diri remaja. Remaja yang merupakan masa pembentukan identitas memerlukan bimbingan untuk melakukan proses self help untuk membantu bangkit dalam permasalahan cinta dan patah hati. Penelitian ini telah dilakukan evaluasi dengan melakukan crosscek kebenaran data yang ditulis kepada subyek utama. Dokumen pendukung yang akan dilampirkan adalah puisi "Dia Sang Pencemburu" karya subyek sebagai ekspresi evaluasi diri selama proses self help yang dilakukan.

33 Yasipin, Y., Rianti, S. A., \& Hidaya, N. (2020). Peran Agama dalam Membentuk Kesehatan Mental Remaja. Manthiq, 5(1), 25-31.

34 Glaser, C. L. (1994). Realists as optimists: Cooperation as self-help. International security, 19(3), 50-90. 


\section{Penutup}

Pembelajaran selama proses kehidupan memberikan pengaruh terhadap pembentukan narasi diri individu. Narasi diri merupakan salah satu faktor pembentuk kepribadian. Narasi diri merupakan seperangkan nilai dan pengalaman yang diinternalisasikan dalam diri. Narasi diri individu yang bersifat destruktif menggangu proses perkembangan. Narasi yang berkembang selama proses kehidupan akan mempengaruhi pemikiran, perasaan dan tindakan individu. Masalah percintaan merupakan penyumbang nilai depresi yang tinggi pada individu. Hasil penelitian menunjukkan bahwa dengan melakukan self help dengan mengembalikan apapun yang terjadi kembali pada Allah adalah keputusan terbaik dan dapat mengurangi deperesi dan memberikan ketenangan batin. Hal ini dapat dilakukan dengan sholat dhuha dan membaca surat demi surat dalam al-Qur'an dengan penuh keyakinan.

\section{Daftar Pustaka}

Abels, Sonia. Understanding Narrative Therapy : A Guidebook For The Social Worker. New York: Springer Publishing Company Inc., 2001.

Amiruddin, Herman. Tak Terima Diputus Pacar,Mahasiswa di Makassar Tewas Gantung Diri. Berita Online, Jakarta: https://news.okezone.com, 2020.

Amiruddin, Herman. Terbakar Api Cemburu,Mahasiswa Gantung Diri di Kamar Kost. Artikel Online, Jakarta: https://news.okezone.com, 2020.

Baenada, Listhari. Mengenal Lebih Jauh Revolusi Industri 4.0. Artikel Online, https://binus.ac.id, 2019.

Barbara, Santa. Circle of Life. Artikel Online, http://www.circleoflife.net, 2011.

Budiningsih, C. A. (2009). Mengembangkan Nilai-Nilai Afektif Dalam Pembelajaran. Yogyakarta: KTP-FIP UNY

Carole Wade, Carol Tavris, Maryanne Garry. Psychology, Eleventh Edition. Canada: Pearson Education, Inc., 2014.

Corey, Gerald. Theory and Practice of Counseling and Psychotherapy Tenth Edition. Boston: Cengage Learning, 2017.

Creswell, John. Educational Research : Planning,Conducting and Evaluating Quantitative and Qualitative Research. Boston: Tex'Tech International, 2012.

Damarjati. Tingkat Bunub Diri Indonesia Dibanding Negara-negara Lain. Berita Online, https://news.detik.com, 2019.

Dhani, Arman. Mati karena Patah Hati. Berita Online, Jakarta: https://tirto.id, 2016.

Erikson, Erik. Identity Youth and Crisis. United States: W.W.Noron \& Company, Inc., 1968. 
Fardiansyah, Achmad. Begini Kronologi Pria Nekat Loncat dari Flyover Senen. Berita Online, Jakarta: https://megapolitan.okezone.com, 2020.

Glaser, C. L. (1994). Realists as optimists: Cooperation as self-help. International security, 19(3), 50-90.

Golden, John. "Understanding Your Personal Values: A Clarification Companion Guide To The Values Arrangement List ${ }^{\mathrm{TM}}$ Assessment." Trademark of Golden LLC, 2016.

Handaru, A. W., Lase, E. P. S., \& Paramita, W. (2014). Analisis perbedaan tingkat prokrastinasi ditinjau dari gender, socio-personal, locus of control, serta kecerdasan emosional: studi pada mahasiswa program studi manajemen fE UNJ.JRMSI-Jurnal Riset Manajemen Sains Indonesia, 5(2), 243-263.

Highland Consulting Group. Leading With Impact: Your Ripple Effect. Artikel Online, www.AskRoxi.com, 2014.

Kementrian Kesehatan Direktorat Promosi Kesehatan dan Pemberdayaan Masayarakat. Pengertian Kesehatan Mental. Artikel Online, Jakarta: https://promkes.kemkes.go.id, 2018.

Mappiare, Andi. "Meramu Model Konseling Berbasis Budaya Nusantara: KIPAS (Konseling Intensif Progresif Adaptif Struktur)." Pidato Pengukiujan Jabatan Guru Besar dalam Bidang Ilmu Bimbingan dan Konseling. Malang: Universitas Negeri Malang, 2017.

Permendikbud. "Peraturan Menteri Pendidikan Dan Kebudayaan Republik Indonesia Nomor 20 Tahun 2018 Tentang Penguatan Pendidikan Karakter Pada Satuan Pendidikan Formal." Salinan Peraturan Menteri. Jakarta, 2018.

Santrock, John. Life-Span Development: Seventeenth Edition. New York: McGrawHill Education, 2019.

Sugiyono. Metode Penelitian Bisnis. Bandung: Pusat Bahasa Depdinas, 2003.

Yasipin, Y., Rianti, S. A., \& Hidaya, N. (2020). Peran Agama dalam Membentuk Kesehatan Mental Remaja. Manthiq, 5(1), 25-31. 
208 | Islamic Counseling: Jurnal Bimbingan dan Konseling Islam, Vol. 4, No. 2, 2020 